\title{
Muslim Perspectives on End-of-Life Issues
}

\section{Moderator:}

Daniel Martin Varisco, PhD

Professor of Anthropology

Hofstra University

Long Island, New York

\section{Panelists:}

Gamal Badawi, PhD

Professor Emeritus of Management and Religious Studies

St. Mary's University

Halifax, Nova Scotia, Canada

Shahid Athar, MD, FACP, FACE

Department of Endocrinology and Medicine

St. Vincent Hospital and

Indiana Unversity School of Medicine

Indianapolis, Indiana

\section{Muslim Attitudes towards End-of-Life Decisions}

Article DOI: http://dx.doi.org/10.5915/43-3-8602

Video DOI: http://dx.doi.org/10.5915/43-3-8602V

\section{Gamal Badawi, PhD}

Attitudes toward end-of-life decisions is a field that is evolving. We are all interested in how to deal with specific cases relating to the theme of this conference. This morning, the panelists dealt with some of these specifics. What is more important long-term is to understand the underlying set of beliefs and orientations that affect the person's attitude toward end-of-life decisions. The focus of this presentation is on Muslim attitudes. You may have heard different speakers, including me, talking about debates on these issues, even within the same faith, and noting what the majority of the community upholds. Therefore, I thought it would be extremely useful, long-term again, to educate ourselves on how jurists go about making interpretations in the Islamic tradi-

Correspondence should be directed to

Gamal Badawi, PhD

jamalbadawi@hotmail.com tion, whether pertaining to bioethics, or any other topic for that matter.

By way of brief introduction, death is inevitably an irreversible experience. It is very democratic and very multicultural in that sense. It accommodates everyone. Broadly speaking, the person's set of beliefs and values do influence his or her attitudes in respect to any decision, medical, or otherwise. This applies to adherents of "traditional" religions as well as adherents to other sets of beliefs, including humanists and atheists.

There is yet another complication. As noted this morning, end-of-life decisions are not made exclusively by an individual person based on beliefs and values. Physicians, health-care professionals, culture, law, family, clergy, and scholars are part of the decision-making process. To dwell on this complex area is too much of a task. Thus, I am limiting my presentation to what I call "an" Islamic perspective. I always try to avoid using the term "the" Islamic perspective. Except for matters that no two Muslims should differ about, no person can claim that his or her interpretation is "the" Islamic perspective. It is simply a perspective that is subject to debate and correction.

One thing to keep in mind also is that when we speak about any topic, we need to examine both the normative or "ideal" aspect as well as what is actually happening, the practical aspect. Islam is not a monolithic faith. It embraces nearly 1.6 billion followers, close to one-fourth of the human race, with a variety of schools of jurisprudence; it is not confined to one group or one culture. To deal with such diversity is a big task that is beyond this presentation. What is doable, and perhaps more useful, is to take Islam's basic normative teachings as they appear in their original primary sources, which are likely to influence most Muslims in some way or the other, regardless of their particular cultures. It is important not to equate normative Islam with "Muslims" or with diverse "Muslim" cultural practices. Such practices may or may not be consonant with Islam's normative teachings. In fact, some may even contradict 
its teachings. Islam as normative teaching is the criterion by which we can evaluate the actions of Muslims and the degrees to which they succeed or fail to live up to its ideals. I believe that the same distinction applies to other faith communities as well. With this in mind, we begin with the foundational and universal Islamic beliefs.

The cornerstone of Islam is the belief in God, the One true God of all. In Arabic God's name is Allah, in French it is Dieu, and in Aramaic, the likely language

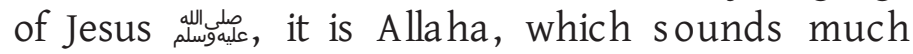
closer to Allah than God and Dieu. After all, Jesus did not speak English or French. I just wanted to make that point clear, because some people mistakenly believe that "Allah" is the god of Mus lims. It is simply the Arabic equivalent to God, the creator of the universe, the same God of all. In fact Arab Christians use the identical term "Allah" to refer to God as do their fellow Mus lims. Variations within and between the three "Abrahamic" religions - C hristianity, J udais $m$, and Is lam - in the ir perceptions or theologies do not mean that they speak about different "gods." I believe further that they share the belief in God's divine attributes. Some such attributes relate to $\mathrm{His}$ transcendence such as power, creation, and so on. These attributes are known in Arabic as the attributes of jalāl, or glory of God Side by side with the attibutes of jaläl are the attributes of jamāl, or grace. That is what theologians probably mean by the term "immanence." This means that God is both transcendent above all creation, yet close to the human, closer than his or her jugular vein to use the Qur'anic expression. ${ }^{1}$ Sometimes I get unsettled when some people continue to claim that in Christianity God is the God of love, but in Judaism and Islam, God is the God of punishment. I do not think this is fair or true. If we were to examine honestly and objectively the three major scriptures - the Hebrew scripture, the New Testament, and the Qur'an - we will find that in all three God is both transcendent and immanent, glorious, yet close, loving, forgiving, and merciful.

The term "Islam" shows that God should be the center of the thinking and attitudes of true Muslims. It is derived from an Arabic root, which connotates two things: peace and submission. It means also purity. Theologically and etymologically, Islam can be defined as the pursuit of peace with God resulting in inner peace that in turn results in peace with all creation of God, which includes all humans, Muslims and people of other faith communities, the world of animals, vegetation, and ecology. Some may say that is a super modern definition. In fact, all elements of this definition can be documented from the 14-century-old primary sources of Islam. The real question is: how can that peace be achieved? The answer derived from Islamic sources is: through willing submission to God diti, acceptance of His guidance, and putting one's trust in Him.

A second major area of belief that relates to what this conference deals with is the concept of the human being. What is human nature? Who is he or she? What is the human mission here on earth? Where is the human going from here? The Qur'an is quite clear in answering these universal questions. You get the distinct implication that the human being is a combination of three interrelated "components": spiritual, which is the more important; intellectual; and physical. These are not three inherently conflicting components but interrelated components that together constitute the human being. ${ }^{2}$

An interesting concept in the Qur'an is that ultimately God is the owner of everything and the ultimate of all. An ethical implication of this concept is that a human does not "own" his or her life, health, or wealth in an absolute and unqualified sense. In other words, a Muslim does not accept such argument as "It is my body. I do with it what I want, and if I decide to commit suicide, it is all up to me." From an Islamic perspective, the human body is a trust from God. Likewise, if a person is ill and there are cures available, it becomes an obligation to seek an appropriate potential cure. This is based on the same notion that health is a trust from God that should be protected and enhanced so as to be able to fulfill the purpose of creation. This broad concept is not totally incompatible with informed autonomy, where a terminally ill person may refuse treatment or painkillers and prefer to let the death process take its course. The argument for seeking medication appears to be stronger. This is closer to what Professor Varisco quoted as well. ${ }^{3}$

Another implication of the concept of trusteeship of humans relates to wealth. When the Qur'an speaks about wealth, some verses attribute ownership to humans using the expression "your wealth," while others attribute ownership to God using the 
expression "the wealth that God gave you." The combined use of both expressions sanctions the right of lawful ownership, while reminding all that the real and ultimate "owner" of the universe is God. As such human ownership is transitory and temporary, a trustee-type of ownership.

While this concept sounds more like theology, it lies at the heart of prohibition of suicide and active euthanasia. The Qur'an states that God created the human being to be His trustee on earth. ${ }^{4}$ A parallel concept to that in the Bible is the stewardship role of the human on earth. It follows that life, health, wealth, and all resources available in this universe are means to help humans fulfill that trust, shaping their lives on earth according to God's commands. According to the Qur'an, God has subjected all that is in the heavens and the earth for human benefit, as a gift from Him..$^{5}$ In other words, all resources or laws that God created are but tools to help humans fulfill their trusteeship roles while on earth. The principle of trusteeship means a trustee is not at liberty to do anything with the wealth or health, property, or resources that God has entrusted in his hands. Just like a lawyer, a trustee is not at liberty to do what he pleases but must act in accordance with the instructions of the "owner" who appointed him. For the Muslim, the terms and conditions of that trust are contained in the Qur'an and the teachings of the

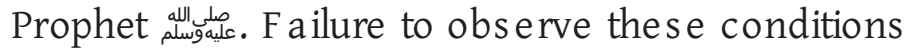
or violating them is to break that trust. Needless to say, humans are free to choose to obey God or not, to believe or not. However, every choice has its own consequences.

A third central belief is the belief in the life hereafter. Some scholars, such as Mawdudi, submit that Islamic ethics are rooted in this belief. Rejecting the certainty of resurrection, accountability before God لs to abide by the rules of $\mathrm{G}$ od ali and the ability to res is temptations to act unrighte ous ly.

Irrespective of the individual belief, nonbelief, or uncertainty about life after death, there is no question about the certainty and inevitability of death itself. As suggested earlier in this presentation, death is very democratic and very multicultural. The Qur'an states that God has created death and life to test the humans as to their conduct in their earthly lives. ${ }^{6}$ The notion of death relates to one's attitudes and way of life. Some may wonder why the Qur'an mentions death before life. They may argue that it sounds more logical to mention life first then death, which is preceded by life. One possible answer to this question is that the elements in the earth (such as iron, sodium, phosphorous), of which the human body is made, have no biological life in themselves. This is analogous to death. This is followed by life, which, in turn, is followed by physical death. This answer is based on accepting the chronological sequence of life and death[s]. A better explanation, which is more contextual to the notion that earthly life is a "test" of the strength of faith and righteousness of action, is to regard the order as one of degree of certainty. The fact that everybody is going to die is absolutely certain, even to those who do not believe in God or are "uncertain" about the existence of God. Life, however, may be less certain and subject to probability. We may be certain that there is life in the mother's womb, but is it guaranteed? Are we absolutely certain there will be no spontaneous abortion or a stillbirth? In other words, death is much more certain and inevitable. This is one example of the eloquence and precision of the Qur'an. According to the Qur'an, God predestines and decrees the moment we will die before we are conceived in the wombs of our mothers. No one can hasten or delay his or her own death or that of others if it is against the will of God, regardless of the cause of death. The Qur'an makes it clear that every soul shall taste death, including the greatest Prophets. ${ }^{7-9}$ That in itself is sort of a consolation and a means of alleviation of the understandable universal human fear of death. Actually, the Qur'an states:

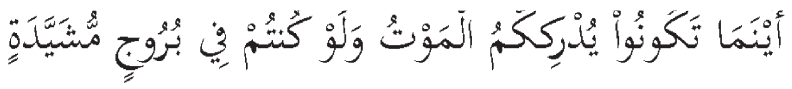

Wherever you are, death will overtake you out, even if you are in towers built up strong and high ... ${ }^{10}$

This is not withstanding individual obligation to save one's life and the lives of others, especially health professionals. When one's destined time of death comes, it comes, neither earlier nor later.

Allow me to share a personal experience with you on this topic. On September 2, 1998, Swiss Air Flight 111 originating from New York on the way to Geneva crashed in the ocean just outside the coast of Nova Scotia, Canada. All 229 people on board were 
killed. In a subsequent interfaith service attended by the families of the victims and officials from the governments of Switzerland and Canada, I quoted a few verses from the Qur'an that ended with the following "... nor does anyone know in what land he or she is to die ..." 11 After the service, a lot of families of the victims came to me, some with tears in their eyes, saying that that quote from the Qur'an was the most moving part of the service. Neither the passengers nor their families ever expected such a fate. As this is the case with the fragile and "uncertain" life, it is a consolation for the believer to submit to the will of God to cope better in his or her hour of grief and mourning.

Muslims' beliefs about death and afterlife influence their attitudes towards end-of-life decisions, more specifically, whether to remove life-support equipments. While death itself is scary, by realization that everyone is returning to God, the experience of death may become, relatively speaking, less scary. For a believer in the afterlife who tried his or her best, death means a transition from one form of existence to another, looking forward to be in the presence of God. That is probably why the Qur'an states that among the most praiseworthy people are those who, when afflicted with the death of a loved one or similar calamity, say:

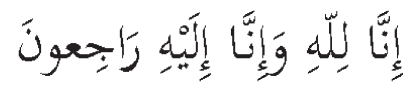

To God we belong and to Him is our return.12

Prophet Muhammad allugate likened life here on earth to a short rest or pause [under the shade of a tree] by a traveler who sets out on a long journey [to eternal life].13

It should be noted that acceptance of destiny, or what God has destined for each person, does not mean fatalism in any way. I was very touched and impressed with what Professor Varisco said this morning. He quoted people who spoke about living as if they were going to live forever while expecting to die at any moment. ${ }^{3}$ Allah dele says:

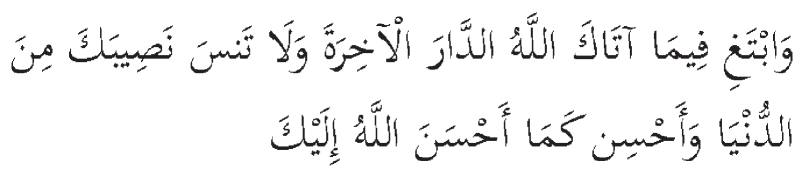

But seek the abode of the Hereafter in that which Allah has given you, and forget not your portion of this world, and be you kind even as Allah has been kind and seek no mischief in the earth for Allah loves not the mischief makers. ${ }^{14}$

This precludes any notion of fatalism in the name of accepting "fate."

The previous discussion pertains to what is known as the first of the five pillars of Islam, or the core beliefs. The other four pillars are the five daily prayers, charity, fasting, and pilgrimage. Remote from the topic as they may appear, they are also related to the question of the end of life. A terminally ill person who is used to performing five daily prayers is likely to continue performing them whenever and however possible (e.g. standing or sitting on a chair or while lying in bed). Every time the patient prays, he or she feels connected to God because prayers are means of direct communion with God with no intermediary. This is likely to reduce anxiety. A person who regularly pays charity will make sure to pay whatever minimum prescribed charity (zakāh) he or she owes to the poor and needy before dying. Some may even bequeath a portion of their estate to charitable causes if they have not done so before. Pillars of Islam are not only consolation to the patient but also to his or her loved ones, both in the terminal period and after death. Prayers help them cope with their grief through connecting with God and seeking His help and reward for patience and being confident that God is always with them.

\section{Sources of Juridical Interpretation}

After this review of the impact of Muslim beliefs and religious practices, it is useful for us to be aware of the manner in which Muslim jurists go about making their interpretation concerning end-of-life situations based on primary Islamic sources. There are only two revelatory sources of Islam.

The first and foremost one is the Qur'an, which is the ultimate source of Islam because it is believed to be the verbatim word of God dis dictated by the arch angel $G$ abriel to Prophet Muhammad allugate. The $Q$ ur'an was simultaneously trans cribed from the mouth of the Prophet allugate and memorized by the masses during his lifetime and under his supervision. The tradition of committing the Qur'an to memory has continued without inter- 
ruption, generation after generation, to the point that today a lot of Muslim children, even 6 or 7 years old and whose mother tongue is not Arabic, memorize the entire Qur'an by heart with the proper intonation and observing the many rules of recitation. Due to its authority being accepted as the word of God and its authenticity due to its meticulous preservation, it is regarded as the "source of sources" in juridical interpretations.

The second source of juridical interpretation after the Qur'an is known as the Hadith or Sunnah, which means the words, actions, and consent or approval of the Prophet eلم in the religious matters. Unlike the Qur'an, which is all authentic, the Hadith has been class ified by its scholars into degrees of authenticity.

If the issue in question is not directly referred to in both primary sources discussed above, juridical interpretation becomes necessary. There are two widely accepted methods of legal interpretation; the first is called ijmā', translated roughly as consensus of the scholars. The second is called qiyās, which means analogical reasoning. For example, if the Qur'an says that anything that clouds the mind (such as wine) is forbidden to Muslims, then substances such as LSD or opium are also forbidden by analogy.

There are other methods of juridical interpretation that are debatable. In any case, it is useful for jurists to keep in mind customs, circumstances, and public welfare. An interesting rule in Islamic jurisprudence is known as "presumption of continuity." For example, if there is any doubt whether a married couple is divorced, then it is presumed that their marital status continues. Likewise, if it is uncertain if a patient is dead (however evolving definition of death is accepted), then continuity of life should be presumed until death otherwise is confirmed.

Rulings of scholars are not binding, and there may be more than one authenticated interpretation of some controversial issues. However, there are also some guidelines or rules that are helpful to mention. There must be some basic qualification of the person who makes a ruling, and whoever is making a ruling must fully understand the issue under consideration. For example, in medical issues, a religious scholar may need to consult with experts, have conferences on specific medical issues, and allow free discussion between religious scholars and medical experts or even to jointly codetermine the solution, especially in complicated issues. Other rules include not doing harm to oneself or others, and harm should be removed but not by committing greater harm. A rule that is pertinent to medical decisions is "a lesser harm is tolerated if it is necessary to mitigate a greater harm." For example, an intrusive surgery may be tolerated if it is necessary to save the patient's life. Another related rule is that necessities may mitigate or allow some of the forbidden things. For example, anesthesia may result in clouding of the mind, which as a rule is forbidden. However, it is necessary to treat the patient or even save his or her life, and that necessity overrides the prohibition.

Juridical interpretation is not to be done in a vacuum. Consideration of the supreme objectives of Shari ah must be done. Unlike what many think, due to widespread misrepresentation of Islam, the supreme objective of Shariah is to benefit the human. The widely accepted objectives, based on the primary sources of Islam, are to protect faith, life, mind, family, and property.

On the basis of the basic faith and universal religious practices, we comment finally on the specific issue of brain death as viewed by some contemporary Muslim jurists. Provided that competent medical experts are able to clearly define brain death and its criteria, the common question is whether life support equipment should continue to be used. The consensus is that there is no obligation to use or continue to use life support equipment if indeed brain death has occurred. The grounds for this view include futility of prolonging agony of loved ones, misuse of financial and human resources and depriving other patients of badly needed equipment. Another question is "Who decides?" This was discussed in some detail during this conference; maybe a joint determination is best. Some of these issues are also included in Dr. Shahid Athar's presentation. ${ }^{15}$ In terminal cases, where the patient cannot survive without life-support equipment, the consensus is that no intervention is needed if an advance directive, such as a do not resuscitate order (DNR), is available. The grounds for that, according to some jurists, is that treatment is not mandatory, and if the patient is capable of making a decision (e.g. DNR), then no intervention or interference in the "death process" is needed. The question that needs to be debated however is: do you remove just the life-support equipment or do you also remove the feeding 
tube? I understand that Dr. Padela is of the opinion that feeding is care, not cure, and one should not aggravate the suffering of the patient. Sheikh Yusuf al-Qardawi has a different view on that. ${ }^{16}$ Another related issue, should the terminally ill be treated for complications such as pneumonia? Some argue that pneumonia itself is not terminal and hence should be treated, especially if its treatment makes the patient more comfortable, unless the physicians decide that treatment is likely to enhance the patient's pain and suffering.

As to active euthanasia, it is totally forbidden in Islam. Suicide or assisting suicide is likewise forbidden. Mitigating pain, however, is permissible.

\section{References}

1. The Glorious Qur'an, Chapter 50, Verse 16.

2. The Glorious Qur'an, Chapter 32, Verses 6-9.

3. Varisco DM. The end of life, the ends of life. J
Islam Med Assoc. 2011;43:203-7.

http://dx.doi.org/10.5915/43-3-7037

4. The Glorious Qur'an, Chapter 2, Verse 30.

5. The Glorious Qur'an, Chapter 45, Verse 13.

6. The Glorious Qur'an, Chapter 67, Verse 2.

7. The Glorious Qur'an, Chapter 3, Verse 185.

8. The Glorious Qur'an, Chapter 21, Verse 25.

9. The Glorious Qur'an, Chapter 29, Verse 57.

10. The Glorious Qur'an, Chapter 4, Verse 78.

11. The Glorious Qur'an, Chapter 31, Verses 33-4.

12. The Glorious Qur'an, Chapter 2, Verse 156.

13. Sunan al-Tirmidhī. Abwāb al-zuhd. Chapter 31.

Hadith no 2483. muhaddith.org

14. The Glorious Qur'an, Chapter 28, Verse 77.

15. Athar S. Advance directives and living wills for Muslims. J Islam Med Assoc. 2011;43:nn-nn.

http://dx.doi.org/10.5915/43-3-8478

16. Al-Qaradawi Y. Min hady al-Islām: Fatāwā mu`āṣira. Dār Al-Wafā’: Al-Manșūra, Egypt; 1993. 